\title{
Physical Education and Sports on the Way to the Digital Era
}

\author{
Eroshkina S.B. \\ Federal Scientific Center Institute \\ Moscow, Russia \\ eroshkina@vniifk.ru
}

\author{
Smirnov S.Yu. \\ Federal Scientific Center Institute \\ Moscow, Russia \\ ssmir@ vniifk.ru \\ Timar O.V. \\ Federal Scientific Center Institute \\ Moscow, Russia \\ olga-1308@vniifk.ru
}

\begin{abstract}
Information systems are used in almost all spheres of human life and, as a rule, are focused on the processing of state, legal (legislative), business, financial, scientific and technical, educational, entertainment and other information. Over the past decades, intensive research has been carried out in the field of information systems development and their fundamental database components, optimal approaches and typical solutions for design and repair have been selected. Official statistical activities in Russia are conducted by more than 60 ministries and departments. The purpose of their statistical work is to create a summary of the social, economic, demographic and environmental development of the country. This information is the basis for strategic decision-making at all levels of government.
\end{abstract}

Keywords-physical culture and sport; software; system; statistics; statistical indicators; analysis; forecasting.

\section{INTRODUCTION}

Speaking about the transition to the digital economy, it is impossible not to notice the transformations that have been taking place in the public administration sector in the last five years, both at the Federal and regional levels. The ubiquity of global networks, the creation of large data centers, the introduction of centralized solutions based on web technologies - all this is the basis for the transition to qualitatively new management solutions based on big data. Such changes have not spared the industry of physical culture and sports.

At the legislative level, it is determined that an effective state policy in the field of physical culture and sports is the most important condition for saving the nation and a leading factor in the growth of human potential. Today, many scientists consider the field of physical culture and sports as a new and promising sector of the national economy, in connection with which, in recent years, in Russia and abroad began to appear more and more theoretical studies relating to a number of important issues in the development of physical culture and sports. But among them, there is little or no notable work on the Economics and management of the industry in the transition to a digital economy.

In modern socio-economic conditions, the development of the economy is provided by many factors, including not only a properly developed economic strategy, but also accounting policy, management system and economic analysis and optimally drawn up development plan. A key role in the implementation of these tasks belongs to economic analysis. Moreover, the more quickly and efficiently it is carried out, the more effective management decisions are made and the more positive changes have a stable positive trend.

The purpose of the study: to substantiate the need to develop a comprehensive assessment of the state and development of the physical culture and sports field in the Russian Federation using an automated system for collecting, processing and analyzing statistical information on the indicators of the field of physical culture and sports.

\section{RESEARCH METHODOLOGY}

The requirements and necessary conditions for ensuring the adoption of effective management decisions in the field of physical culture are considered, as well as a comparative analysis of existing software products that allow in one or another part to automate the processes of collecting and processing information in the field of physical culture and sports.

\section{RESULT}

Currently, the topic of transition to a digital economy, which was first outlined by Russian President Vladimir Putin in his last Address to the Federal Assembly and which was subsequently supported by Prime Minister Dmitry Medvedev in his speech at the Investment forum in Sochi, is being actively discussed in scientific circles. As part of the transition to the digital economy, two conceptual strategies have been adopted The strategy for the development of the information society in the Russian Federation for 2017-2030 
and the Strategy for economic security of the Russian Federation for the period up to 2030. They set the vector of development and national priorities for the long term-the introduction of new formats of public administration and the transition to a digital economy.

Thus in our opinion, for management of the processes occurring in the sphere of physical culture and sports, it is necessary, first of all, to collect the most complete and qualitative information reflecting the most accurate picture of physical culture and sports branch development condition in the Russian Federation, and also to systematize it on all indicators of a condition and development of branch in dynamics. Now partially these data can be received from forms of Federal statistical supervision 1-FC "Data on physical culture and sport", 5-FC "Data on the organizations which are carrying out sports preparation" and 3-AFK "Data on adaptive physical culture and sport" [1].

To analyze the indicators contained in these forms, it is necessary to conduct a large number of additional studies, check and recheck the available statistical data, select factors and determine the relationship between the indicators both within the sphere of physical culture and sports, and with the indicators of the other economy sphere by the method of extended analysis. Such studies are time-consuming and carry significant risks of erroneous results due to the human factor. At the same time, it is necessary to develop a strategically competent decision in the conditions of constant changes in the economic and political spheres very quickly and efficiently, and sometimes a lot depends on the speed of decision-making. This raises the question of whether everything was taken into account in the analysis, whether the influencing factors were chosen correctly, whether there is enough data and, most importantly, whether they are reliable.

The methods of the phenomena and processes of physical culture movement quantitative regularities analysis are based on general scientific approaches to the knowledge of reality: comparison, analysis, synthesis, relationship, development, forecast, etc.

In the study of the state and development of physical culture and sports methods of comparison are found at almost every step. Once the level of any phenomenon, such as mass physical culture movement, is determined, it immediately becomes necessary to answer the questions, what happens to it, in what direction it changes, that is, to give a comprehensive description of the result. To achieve this goal, resort to comparisons. Only by means of the indicators economic analysis in dynamics it is possible to reveal character of the occurred shifts [2].

Economic analysis is the most important tool in the management system, it is considered as an element in the decision-making chain (analysis-planning-organization) and represents an important stage in the preparation and adoption of management decisions.

In modern conditions of transition to a digital economy, where speed and quality of decisions depends on the future development of the industry there is a need for a system of comprehensive assessment and development of physical culture and sports in the Russian Federation with the use of the automated system of collection, processing and analysis of statistical information on indicators of physical culture and sports industry.

At the same time, there are currently several software products that allow in one way or another to automate the processes of collecting and processing information in the field of physical culture and sports. Among them:

1) the automated information system "IAS Sports" is a state automated information system of Moscow city providing Executive authorities, citizens and organizations to information about sports facilities, sports services, and events [3].

2) AIS "Physical culture and sport" is implemented in Gubkinsky Yamal-Nenets Autonomous Okrug and is intended for automation of the municipal bodies activity providing carrying out of uniform state policy in the field of physical culture and sport and carrying out the management of physical culture and sport municipal system. This program is designed for recording and accumulation of information about objects of physical culture and sports in the territory of the municipality, about sports clubs and groups operating on the territory of the municipality, maintaining records of sports events, objects, city events, and collect data content of the citizen and his sports activities.

3) Information and analytical system " BARS. Monitoring-Sport " is designed for centralized collection, consolidation and analysis of arbitrary reporting on physical culture and sports in the Krasnoyarsk region.

The described software products are aimed at achieving individual goals:

a) for convenience for citizens of the Russian Federation when registering children in certain sports organizations, to view information about a particular section or club, when choosing a coach, price guidelines;

b) for reporting on competitions and other sports events;

c) to inform citizens about the conduct of certain sports events, their orientation and rules of participation;

d) to simplify the process of collecting statistical information at the level of the Russian Federation subject for the formation of statistical reporting forms.

At the same time, a large number of information technologies are devoted to the creation of automated systems and application software products that simplify the management of the training process. Attention is also paid to improving the quality of athletes technical training. To do this, the development of systems is carried out in the direction of creating software and hardware complexes that allow to automate data entry and calculate the necessary biomechanical parameters.

Another area of information technology use is associated with the development of programs for health physical culture.

In order to introduce the younger generation to the sport, a computer program "Valeology of the student"is being 
collection, transmission, processing and presentation of

developed. Its task is to collect, analyze and store the results of valeological monitoring for adolescents and children [4].

Recently, such a tool for evaluating athletes as video analysis has become especially popular. Video analysis in sport refers to the recording of information on video about the movements of athletes and the subsequent processing of the information received.

The most famous are:

- BioMovie software developed in Italy, and designed for video analysis not only in sports, but also for medical purposes. The main advantage of this program is the ease of use and intuitive interface. The program supports express analysis, automatic data saving, data exchange via the Internet;

- software of the Swiss company Dartfish, which allows to record and analyze biometric and biomechanical data of the athlete, without interrupting training.

- video analysis system TEMPLO-allows to integrate various external indicators of measuring systems and to carry out their further systematization necessary for identification of regularities in the process of sports activity - for the analysis of walking, running, jumping, posture, sports analysis, etc. [4].

\section{CONCLUSION}

Based on the above, it can be concluded that the existing software products do not allow to assess the state of the physical culture and sports industry in the Russian Federation and do not have the ability to conduct a comprehensive analysis of its future development. This conclusion confirms the authors ' opinion on the need to develop a comprehensive assessment of the state and development of the industry with the use of an automated system of collection, processing and analysis of statistical information for operational and qualitative economic and statistical analysis in order to develop and make the most effective management decision.

The development of the above system is directly dependent on the development of technologies for the information.

The methods and approaches by which these problems have been solved so far do not meet modern technological requirements and are not suitable for further application. On the one hand, this is due to the fact that the volume of information collected increases, and its composition changes every year, while at each level of the physical culture and sports industry management, the composition of information differs. On the other hand, the class of systems providing analytical processing of information and providing convenient means of data visualization is not represented in the regions of Russia, and the need for them today is very large $[5,6,7]$.

\section{References}

[1] Website of the Ministry of sports of the Russian Federation. URL: http://www.minsport.gov.ru.

[2] Karmanov M. V. Methodology of statistical research and forecasting of physical culture and sport development. Dissercat scientific library of dissertations and abstracts. URL: http://www.dissercat.com/content/metodologiya-statisticheskogoissledovaniya-i-prognozirovanie-razvitiya-fizicheskoi-kultury\#ixzz5iET4fcDZ.

[3] Resolution of the government of Moscow of 22.04.2014 No. 203-PP.

[4] "About the automated information system" Information-analytical system of sports branch of the city of Moscow". URL: http://docs.cntd.ru/document/537953810 http://docs.cntd.ru/document/537953810.

[5] Savelyeva O. V., Ivanova L. A. Analysis of information technologies in the field of physical culture and sport. Concept. 2015, 8. URL: http://ekoncept.ru/2015/15273.htm.

[6] Ivanov A. N., Zotin A. G. Development of analytical system of data processing of treated persons in hospitals of the city of Krasnoyarsk / / Scientific electronic library "Cyberleninka". URL: https://cyberleninka.ru/article/n/razrabotka-analiticheskoy-sistemyobrabotki-dannyh-prolechennyh-lits-v-statsionarah-gorodakrasnoyarska. (date accessed: 15.08.2019).

[7] Alexsandr S. Kuznetsov. Russian Professor's meeting. Russian Journal of Physical Education and Sport. 2019, 14(1), pp. 17-22. DOI: 10.14526/2070-4798-2019-14-1-18-24

[8] Evdokimov D. A. Means of automation of collection and processing of medical statistical information. URL: https://www.dissercat.com/content/sredstva-avtomatizatsii-sbora-iobrabotki-meditsinskoi-statisticheskoi-informatsii. 